\title{
Growth and fillet yield in recirculation systems of Lobotes pacificus (Perciformes: Lobotidae), a species with aquaculture potential
}

\section{Crecimiento y rendimiento en filete de Lobotes pacificus (Perciformes: Lobotidae) en sistemas recirculados, una especie con potencial en acuicultura}

\author{
Jonathan Chacón-Guzmán ${ }^{1-2^{*}}$, Milagro Carvajal-Oses ${ }^{1-2}$, Ángel Herrera-Ulloa ${ }^{1-2} \&$ \\ Pedro Toledo- Agüero ${ }^{3}$
}

\begin{abstract}
The genus Lobotes extends across tropical and subtropical areas of oceans such as the Atlantic and the Pacific; it is extracted in artisanal fisheries, and its aquaculture production technology is still under investigation. The objective of this paper was to evaluate the growth and fillet yield of L. pacificus in recirculated systems. In 2014, for a 100-day period, 132 juveniles were placed in six $10 \mathrm{~m}^{3}$ tanks (22 fish/tank), D1 (ranging 5-13 g, $\overline{\mathrm{x}}=8.8 \pm 1.9 \mathrm{~g}, \mathrm{n}=66$ ), and D2 (ranging 14-80 $\mathrm{g}, \overline{\mathrm{x}}=44.7 \pm 16.4 \mathrm{~g}, \mathrm{n}=66$ ). Fish were fed to satiety, D1 with artificial feed and D2 with sardines. The weight-length relationship was calculated for each group. Fish had a final weight of 47.7 $\pm 20.3 \mathrm{~g}$ and $612.2 \pm 238.7 \mathrm{~g}$ in groups D1 and D2, respectively, while survival was $98.3 \%$ and $72.7 \%$ in groups D1 and D2. The whole fish and fillet yields (whole eviscerated fish yield of 89.0 $\pm 0.5 \%$ and fillet yields without skin of $36.1 \pm 0.6 \%$ ) from group D2 were considered acceptable and competitive. The 100 days of culture indicated that L. pacificus reached commercial sizes in less time than other similar fish species; however, the use of sardines as the only source of food was not recommended. This study showed that L. pacificus has high yield potential for aquaculture.
\end{abstract}

Keywords: Tripletail, juveniles, weight, commerce, culture

\section{RESUMEN}

El género Lobotes se extiende por las zonas tropicales y subtropicales de océanos como el Atlántico y Pacífico; se extrae de manera artesanal y su tecnología de producción acuícola aún

1 Programa Parque Marino del Pacífico, Escuela de Ciencias Biológicas, Universidad Nacional (UNA), Heredia, Costa Rica. jonathan.chacon.guzman@una.cr*

2 Laboratorio de Investigación y Desarrollo en Acuicultura y Biotecnología Marina, Parque Marino del Pacífico (PMP), 500 m oeste del Muelle de Cruceros, Puntarenas, Costa Rica.

3 Departamento de Acuicultura, Facultad de Ciencias del Mar, Universidad Católica del Norte, Coquimbo, Chile. 
está en investigación. El objetivo del presente trabajo fue evaluar el crecimiento del cuerpo y el rendimiento del filete en L. pacificus en sistemas recirculados. En el 2014 y durante 100 días se colocaron 132 juveniles en seis tanques de $10 \mathrm{~m}^{3}$ (22 / tanque), D1 (rango 5-13 g, $\overline{\mathrm{x}}=8.8 \pm 1.9$ $\mathrm{g}, \mathrm{n}=66$ ) y D2 (rango 14-80 g, $\overline{\mathrm{x}}=44.7 \pm 16.4 \mathrm{~g}, \mathrm{n}=66$ ). Se alimentaron a saciedad, D1 con alimento artificial y D2 con sardinas. Se calculó la relación longitud peso para cada grupo. Se obtuvo un peso final para D1 de $47.7 \pm 20.3 \mathrm{~g}$., mientras que para D2 fue de $612.2 \pm 238.7 \mathrm{~g}$. Se alcanzó una supervivencia para D1 de 98.3\%; y para D2 fue de $72.7 \%$. Los rendimientos de pescado entero y filete se consideran aceptables en el grupo D2 (pescado eviscerado total $89.0 \pm$ $0.5 \%$ y filete sin piel $36.1 \pm 0.6 \%$ ). Después de 100 días de cultivos esta especie alcanzó mayores tamaños comerciales que otros peces similares, sin embargo, no es recomendable la utilización de sardinas como único alimento. Este estudio demostró que L. pacificus tiene un alto potencial de rendimiento para el cultivo.

Palabras clave: Triplecola, juveniles, peso, comercio, cultivo

\section{INTRODUCTION}

The genus Lobotes has two described species, Lobotes surinamensis, distributed in the tropical and subtropical areas of the Atlantic, Indian, and Pacific oceans (west), and Lobotes pacificus, distributed in the Eastern Pacific, from southern California in the U.S.A. to Peru (Heemstra, 1995). Both species, known as tripletail, are very similar in behavior and morphology, which has led to a controversy over whether the genus is monotypic with $L$. surinamensis as the only species with a circumglobal distribution (Tortonese, 1990), or if it contains two species (Lea \& Rosenblatt, 2000; Nelson et al. 2004; Zemnukhov \& Turanov, 2011).

Lobotes pacificus is a benthopelagic fish that can be found in estuaries and in the open sea grouped around floating objects. The species feeds on crustaceans and other fish and can reach up to $1 \mathrm{~m}$ in total length (TL) (Heemstra, 1995; Lea et al. 2010). It is commercialized fresh and frozen for human consumption (Heemstra, 1995). Its white meat is popular in local markets due to its texture and flavor (Ramírez, 2004). In Costa Rica, Murase et al. (2014) reported it as a small portion of the fisheries captured in the Gulf of Nicoya, where it reaches prices between US\$6 and US\$8 per $\mathrm{kg}^{-1}$. In Colombia, its harvesting is reported in artisanal fisheries with an average catch size of $56.6 \mathrm{~cm}$ TL, and a total length-gutted weight relationship of $\mathrm{W}=0.060 \times \mathrm{TL}^{2.656}, \mathrm{R}^{2}$ $=0.936$; determined by Ricker (1975), who also found the slope between the logarithm of weight against the logarithm of length, suggesting that this species grows allometrically (Arias et al. 2007). 
In Central America there are no reports of aquaculture for tripletail species. However, in the case of $L$. surinamensis, Franks et al. (2001) studied the growth in captivity of 27 wild juveniles caught on the Mississippi coast of the U.S.A. Initiating with a weight range of 3.2$34.7 \mathrm{~g}$, the final growth rate was $4.6 \mathrm{~g}$ day $^{-1}$, and the average weight gain was $1011 \mathrm{~g}$ during the 210 days of culture. The objective of the present paper was to evaluate the growth and fillet yields of $L$. pacificus in a recirculation system using two independent tests.

\section{MATERIALS AND METHODS}

\section{Location, capture, and} acclimatization: a total of 132 juveniles of L. pacificus were caught in November 2014 with hand nets in areas with abundant natural floating substrates, in the Gulf of Nicoya on the Costa Rican Pacific coast (9॰ 52' 21.45" N - 9 50 ' 33.08' N, $84^{\circ} 45^{\prime} 32.70^{\prime \prime} \mathrm{W}-84^{\circ} 50^{\prime} 46^{\prime}$ ' W). Juveniles were transported to the Research and Development Laboratory in Aquaculture and Marine Biotechnology (Laboratorio de Investigación y Desarrollo en Acuicultura y Biotecnología Marina$L A B)$ of the Pacific Marine Park (Parque Marino del Pacífico-PMP). Captured fish were bathed in fresh water for $3 \mathrm{~min}$ and $100 \mathrm{ppm}$ of $\mathrm{H}_{2} \mathrm{O}_{2}$ at a $50 \%$ concentration for $1 \mathrm{~h}$. Due to the heterogeneity of the fish caught, subjects were divided by weight ranges, from 5 to $13 \mathrm{~g}$ (group D1) and from 14 to $80 \mathrm{~g}$ (group D2). The fish were acclimatized for 15 days to the food and culture conditions in the lab (photoperiod 12:12, temperature $28 \pm$ $0.5{ }^{\circ} \mathrm{C}, \mathrm{pH} 8$ and salinity 31 parts per million). The growth of both groups was evaluated during the first 100 days. All procedures were conducted in agreement with the legal requirements of the Costa Rican animal welfare law (Asamblea Legislativa de la República de Costa Rica, 1994).

Culture conditions: Each group was studied over a period of 100 days in six $10 \mathrm{~m}^{3}$ circular fiberglass tanks. Each tank was equipped with a Pentair Aquatic Eco-System ${ }^{\circledR}$ recirculation system (UV, 1/2 HP centrifugal pump, foam fractionators, mechanical and biological filter). Water exchange was five times the volume of the tank per day. The following parameters were measured once a day: salinity (g L ${ }^{-1}$ ) with a Red Sea RS7945 light refractometer, dissolved oxygen (mg $\left.\mathrm{L}^{-1}\right)$, and temperature $\left({ }^{\circ} \mathrm{C}\right)$ using a HANNA HI9146 oxygen meter and pH with a HANNA $\mathrm{pH}$ meter $\mathrm{pH}$ EP4. Twice a week, dissolved ammonium $\left(\mathrm{NH}_{3} / \mathrm{NH}_{4}+\right)$ and nitrite $\left(\mathrm{NO}_{2}\right)$ were measured with a Red Sea Colorimetric Test Kit (Table 1). 
Table 1. Average values of physical and chemical variables obtained in the culture tanks of Lobotes pacificus, for each feeding group

Cuadro 1. Valores promedio de las variables físicas y químicas obtenidas en los tanques de cultivo de Lobotes pacificus, para cada grupo de alimentación

\begin{tabular}{lllllll}
\hline Group & $\begin{array}{l}\text { Temperature } \\
{ }^{\circ} \mathbf{C}\end{array}$ & $\begin{array}{l}\text { Oxygen } \\
\mathbf{m g ~ L}^{-1}\end{array}$ & $\mathbf{p H}$ & $\begin{array}{l}\mathbf{N H}_{3} / \mathbf{N H}^{+} \\
\left(\mathbf{m g ~ L}^{-1}\right)\end{array}$ & $\begin{array}{l}\text { Nitrites } \\
\left(\mathbf{m g ~ L}^{-1}\right)\end{array}$ & $\begin{array}{l}\text { Salinity } \\
\mathbf{g ~ L}^{-1}\end{array}$ \\
\hline D1 & $29.36 \pm 0.37$ & $6.23 \pm 0.12$ & $8.56 \pm 0.09$ & $0.01 \pm 0.06$ & $0.03 \pm 0.06$ & $27.58 \pm 1.53$ \\
D2 & $29.37 \pm 0.70$ & $6.26 \pm 0.30$ & $8.26 \pm 0.33$ & $0.23 \pm 0.58$ & $0.36 \pm 0.44$ & $29.71 \pm 1.26$ \\
\hline
\end{tabular}

\section{Experimental design and} feeding: Each group of L. pacificus was analyzed in triplicate. Individuals in treatment 1 (D1, $\mathrm{n}=66,22$ individuals per tank), with a mean weight of $8.8 \pm$ $1.9 \mathrm{~g}$, were fed with $4 \times 4 \mathrm{~mm}$ extruded neutral buoyancy feed, commercially prepared for L. guttatus (50\% protein, $12 \%$ lipids, $4659 \mathrm{Kcal} \mathrm{Kg}^{-1}$ energy, $2 \%$ crude fiber, $12 \%$ ash and $1.6 \%$ phosphorus). Juveniles in treatment 2 (D2, $n=66,22$ each tank), with a mean weight of $44.7 \pm 16.4 \mathrm{~g}$, were fed with pieces of frozen sardine Opisthonema libertate $(23.38 \pm 0.01 \%$ protein and $1.46 \pm 0.56 \%$ lipids). Fish were fed to satiety three times a day (at 07,11 , and 16h). Food rations were weighed before feeding, and uneaten food was weighed $30 \mathrm{~min}$ after and subtracted from initial amount to calculate consumption. In addition, daily mortality was monitored in each tank.

\section{Data collection and analysis:} Fish were sampled every 14 days. In each sampling, fish were anesthetized with essential clove oil (2 metoxi-4(2-propenyl) phenol) (40ppm) and individually weighed using an Ohaus digital scale, model Traveler TA3001, with a precision of $\pm 0.1 \mathrm{~g}$. Total length (TL) was determined in $\mathrm{cm}$ using a $100 \mathrm{~cm}$ Wildco ichthyometer. The following growth rates were calculated from this data:

Absolute growth (Busacker et al. 1990):

$$
\Delta G_{(g \cdot)}: W f-W i
$$

Absolute growth rate (Botero \& Ospina, 2003):

$$
\operatorname{AGR}_{\left(\frac{g}{d a y}\right)}=\frac{W f-W i}{T}
$$

Specific growth rate (Botero \& Ospina, 2003):

$$
S G R_{\left(\% \text { body } \frac{\text { weight }}{d}\right)}=\left(\frac{(\ln W f-\ln W i)}{t}\right) * 100
$$

Food conversion factor (Jobling, 1994):

$$
F C F=\frac{\text { feed provided }}{\text { total weight increase }}
$$

Survival rate:

(Final number of individuals - Initial number of individuals) * 100 
Where $\mathrm{Wf}=$ final average weight $(\mathrm{g}), \mathrm{Wi}=$ initial average weight $(\mathrm{g})$, and $\mathrm{T}=$ number of days in the period.

To determine significant differences of weight averages between treatments, a one-factor analysis of variance (ANOVA) ( $P$ $<0.05)$ was conducted using the statistical program InfoStat (Di Rienzo et al. 2018). Finally, the length-weight relationship (LWR) was estimated with a regression analysis based on the Ricker equation (1975):

$$
W T=a T L^{b}
$$

Where $\mathrm{WT}=$ is the total weight of fish (g), a = regression constant, TL $=$ total length in centimeters, and $b=$ growth coefficient of the regression. A value of $b=3$ indicates isometric growth, while values of $b<3$ indicate negative allometric growth, and values of $b>3$ indicate positive allometric growth (Ricker, 1975). Using the weight and total length data for each sampling period, the condition factor $(K)$ mentioned by Froese (2006) was determined:

$$
K=\left(\frac{W}{T L^{3}}\right) * 100
$$

Whole fish and fillet yield: At the end of the experiment, 12 fish from group D2 were slaughtered, eviscerated, and filleted to determine yields, round fish, fillet with and without skin. Based on the variability of the weights obtained, the group was divided into four sizes: small fish less than $600 \mathrm{~g}$, from which no fillet is obtained, weights between 600 and $750 \mathrm{~g}$; weights between 750 and 900 $\mathrm{g}$, and fish greater than $900 \mathrm{~g}$. For each size, three fish were selected, one for each repetition (Size 1: final average weight $456 \pm 27.5 \mathrm{~g}$, size 2: $707 \pm$ 64.45, size 3: $832 \pm 14$ and size 4 : $916.6 \pm 26.95 \mathrm{~g})$.

\section{RESULTS}

Wild juveniles of L. pacificus adapted to the conditions of captivity. Fish of group D2 suffered skin and gill infestations by the monogenic fluke Benedenia sp. The infestation was controlled with baths of $150 \mathrm{ppm}$ of $\mathrm{H}_{2} \mathrm{O}_{2}$ (50\% concentration) for $1 \mathrm{~h}$, plus fresh water baths for 2-3 min. Average physical-chemical variables obtained during the study period are shown in Table 1.

Food and growth: Table 2 shows the results corresponding to growth parameters calculated during the study period. 
Table 2. Variables and growth parameters, food conversion ratio, and survival in the culture of two groups of wild juveniles of L. pacificus grown in recirculation systems. Wi (g): average initial weight; Wf (g): average final weight; AGR (g day $\left.^{-1}\right)$ : absolute growth rate; SGR (\%BW day $\left.^{-1}\right)$ : Specific growth rate; FCR: food conversion ratio

Cuadro 2. Variables y parámetros de crecimiento, relación de conversión de alimentos, y supervivencia en el cultivo de dos grupos de juveniles silvestres de L. pacificus cultivados en sistemas de recirculación. Pi (g): promedio peso inicial; Pf (g): promedio de peso final; TCA (g day $\left.{ }^{-1}\right)$ : tasa de crecimiento absoluta; TCE (\% PC day $\left.^{-1}\right)$ : tasa de crecimiento específica; RCA: relación de conversión de alimento

\begin{tabular}{|c|c|c|c|c|c|c|c|c|}
\hline \multicolumn{5}{|c|}{ Diet D1 } & \multicolumn{4}{|c|}{ Diet D2 } \\
\hline Parameters & T1 & $\mathbf{T 2}$ & T3 & Average & T4 & T5 & T6 & Average \\
\hline Wi (g) & $\begin{array}{c}9.5 \pm \\
3.7\end{array}$ & $\begin{array}{c}8.8 \pm \\
3.1\end{array}$ & $\begin{array}{c}8.2 \pm \\
3.7\end{array}$ & $8.8 \pm 1.9$ & $\begin{array}{c}46.3 \pm \\
15.6\end{array}$ & $\begin{array}{l}38.1 \pm \\
18.3\end{array}$ & $\begin{array}{c}49.7 \pm \\
13.4\end{array}$ & $\begin{array}{c}44.7 \pm \\
16.4\end{array}$ \\
\hline Wf $(g)$ & $\begin{array}{c}48.0 \pm \\
24.2\end{array}$ & $\begin{array}{c}54.6 \pm \\
20.6\end{array}$ & $\begin{array}{c}40.5 \pm \\
12.3\end{array}$ & $\begin{array}{c}47.7 \pm \\
20.3\end{array}$ & $\begin{array}{c}757.7 \pm \\
225.3\end{array}$ & $\begin{array}{c}459.1 \pm \\
190.1\end{array}$ & $\begin{array}{c}619.7 \pm \\
214.6\end{array}$ & $\begin{array}{c}612.2 \pm \\
238.7\end{array}$ \\
\hline $\begin{array}{c}\text { AGR (g } \\
\text { day-1) }\end{array}$ & 0.4 & 0.5 & 0.3 & $0.4 \pm 0.1$ & 7.2 & 4.2 & 5.7 & $\begin{array}{l}5.7 \pm \\
1.5\end{array}$ \\
\hline $\begin{array}{c}\text { SGR }(\% P C \\
\text { day-1) }\end{array}$ & 1.6 & 1.8 & 1.6 & $1.7 \pm 0.1$ & 2.8 & 2.5 & 2.5 & $\begin{array}{l}2.6 \pm \\
0.2\end{array}$ \\
\hline FCR & 2 & 1.8 & 2 & $\begin{array}{c}1.94 \pm \\
0.4\end{array}$ & 4.1 & 5.8 & 4.9 & $4.9 \pm 3.3$ \\
\hline Survival \% & 100 & 100 & 95 & $\begin{array}{c}98.3 \pm \\
2.9\end{array}$ & 77.3 & 72.7 & 68.2 & $\begin{array}{c}72.7 \pm \\
4.5\end{array}$ \\
\hline
\end{tabular}

Fish in group D1 did not accept the food or quantities provided, which generated low performance for individual growth. On the other hand, fish in group D2 consumed almost all of the sardine provided. In terms of final weight, due to the difference in initial weights, the statistical comparison of the averages between both treatments showed that there were significant differences (ANOVA, $P<0.05$ ) where D2 was the highest final weight.

The analysis of the total lengthweight relationship of individuals in D1 and D2 is presented in Figure 1. R2 values were close to 1 , while $b$ values were lower than 3 in D1 and higher than 3 in D2. The condition factor $(\mathrm{K})$ 
decreased from the first cultivation increased in the first three periods and period to the second in D1 (each decreased in the fourth period as well time period corresponds to 20 days), as in the seventh period (Fig. 2). remaining constant after that. In D2 it
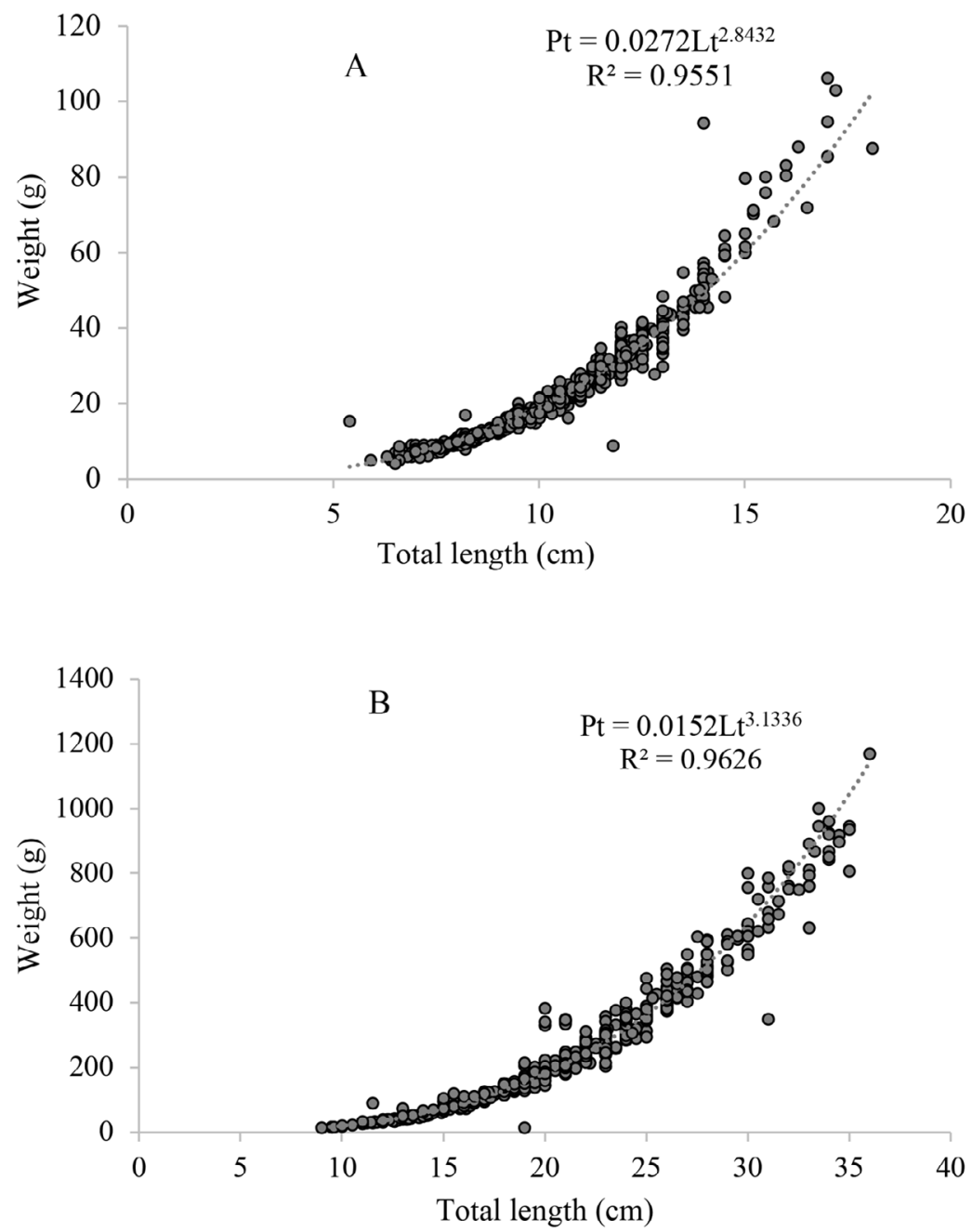

Fig. 1. Total Length - Weight relationship between fish in treatment D1 (A) and treatment D2 (B)

Fig. 1. Longitud total - Relación de peso en peces del tratamiento D1 (A) y peces del tratamiento D2 (B) 


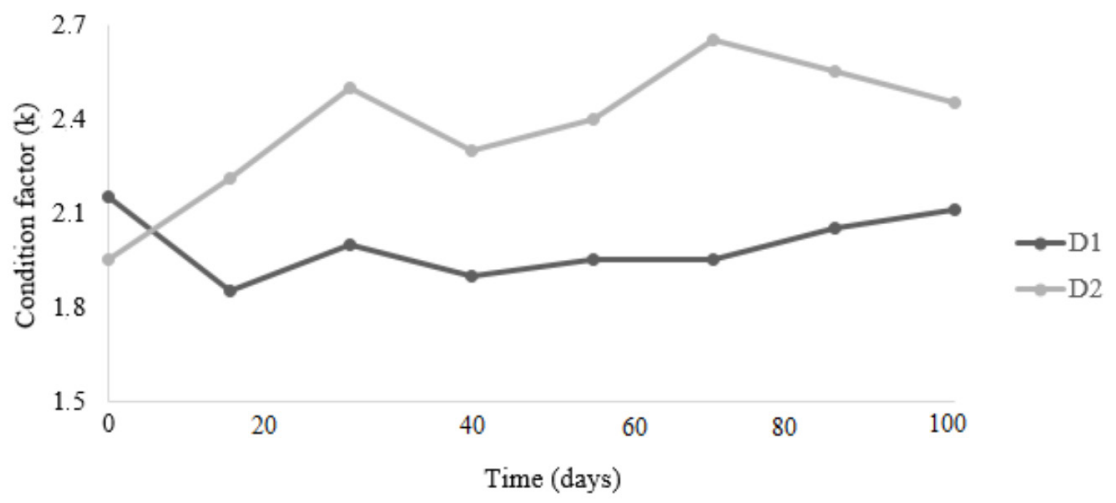

Fig. 2. Variation in the condition factor during the entire study period, for two groups of L. pacificus juveniles grown in recirculation systems in the Pacific Marine Park

Fig. 2. Comportamiento del factor condición durante todo el período de estudio, para dos grupos de juveniles de L. pacificus cultivados en sistemas de recirculación en el Parque Marino del Pacífico

Table 3. Yield parameters for L. pacificus specimens grown in recirculation systems in the Pacific Marine Park, fed with a wet diet established for four potential market niches

Cuadro 3. Parámetros de rendimiento para especímenes de L. pacificus cultivados en sistemas de recirculación en el Parque Marino del Pacífico, alimentados con una dieta húmeda establecida para cuatro nichos de mercado potenciales

\begin{tabular}{|c|c|c|c|c|c|}
\hline $\begin{array}{l}\text { Parameters/weights according to } \\
\text { niche }\end{array}$ & $\begin{array}{l}\text { Fish } \\
456 \pm 27.5 \mathrm{~g}\end{array}$ & $\begin{array}{l}\text { Fish } \\
707 \pm 64.45 \mathrm{~g}\end{array}$ & $\begin{array}{l}\text { Fish } \\
832 \pm 14 \mathrm{~g}\end{array}$ & $\begin{array}{l}\text { Fish } \\
916.16 \pm 26.85 \mathrm{~g}\end{array}$ & Average \\
\hline Average length analyzed $(\mathrm{cm})$ & $26.5 \pm 0.9$ & $30.8 \pm 0.8$ & $34.2 \pm 1.3$ & $35.2 \pm 0.3$ & \\
\hline Average weight analyzed (g) & $426 \pm 27$ & $707 \pm 64$ & $832 \pm 14$ & $916 \pm 27$ & \\
\hline Average eviscerated yield (\%) & $88.2 \pm 1.7$ & $89.4 \pm 0.8$ & $89.2 \pm 0.8$ & $89.0 \pm 0.2$ & $89.0 \pm 0.5$ \\
\hline Average weight of fillet with skin (g) & & $320.3 \pm 40.1$ & $366.0 \pm 4.0$ & $409.3 \pm 4.0$ & \\
\hline Total yield of fillets with skin (\%) & & $45.2 \pm 1.7$ & $43.9 \pm 0.5$ & $44.7 \pm 1.2$ & $44.6 \pm 0.6$ \\
\hline $\begin{array}{l}\text { Average weight of fillet without skin } \\
\text { (g) }\end{array}$ & & $252.0 \pm 36.0$ & $304.0 \pm 0.7$ & $332.0 \pm 9.5$ & \\
\hline Total yield of fillets without skin (\%) & & $35.5 \pm 2.4$ & $36.6 \pm 1.1$ & $36.3 \pm 1.9$ & $36.1 \pm 0.6$ \\
\hline
\end{tabular}

Meat yield: Regarding yields, eviscerated fish and fillets with skin and without skin were similar for all the sizes analyzed (Table 3). 


\section{DISCUSSION}

L. pacificus juveniles adapted to captivity in recirculating systems. Physical-chemical variables of seawater in each period (Table 1), temperature $\left({ }^{\circ} \mathrm{C}\right)$, salinity $\left(\mathrm{g} \mathrm{L}^{-1}\right)$, $\mathrm{pH}$, and oxygen $\left(\mathrm{mg} \mathrm{L}^{-1}\right)$ dissolved, remained stable, constant, and similar to those found in the outer part of the Gulf of Nicoya (García-Rojas et al. 2017). The average of the $\mathrm{NH}_{3} / \mathrm{NH}_{4}^{+}$ balance and $\mathrm{NO}_{2}^{-}$nitrites, although higher in D2 because of the feed used, did not appear to show negative effects on the fish. Ammonia and nitrites were within the values considered safe for culture juveniles off marine fish species such as Dicentrarchus labrax and Pagellus bogaraveo $\mathrm{NH}_{3} / \mathrm{NH}_{4}^{+}$, and nitrites $\mathrm{NO}_{2}^{-}<0.5 \mathrm{mg} \mathrm{L}^{-1}$ (Blancheton, 2000). Salinity of group D2 was higher due to a lower rainfall index during this period, and temperature remained constant in each period.

The Absolute Growth Rate (AGR) found in D2 (Table 2) places L. pacificus among a select group of species with high growth rates, such as Rachycentron canadum with 16.7 and $12.1 \mathrm{~g} \mathrm{day}^{-1}$ (Benetti et al. 2010); Epinephelus itajara with 6.83 and $12.4 \mathrm{~g} \mathrm{day}^{-1}$ (Botero \& Ospina, 2003); Seriola rivoleana with $5.3 \mathrm{~g}$ day $^{-1}$ (Benitez-Hernández et al. 2017), Oreochromis niloticus with values recorded between 3.29 and $4.47 \mathrm{~g}$ day $^{-1}$ (Lima-Amancio et al. 2014), Lutjanus analis with $3.16 \mathrm{~g}$ day (Botero \& Ospina, 2002), Sciaenops ocellatus with $2.7 \mathrm{~g}_{\text {day }}{ }^{-1}$ (Vela et al. 2018), and Lutjanus guttatus with $1.58 \mathrm{~g} \mathrm{day}^{-1}$ (Castillo-Vargasmachuca et al. 2016). Compared to juveniles of other commercial marine fish studied in recirculation systems, SGR of $L$. pacificus was lower than the range reported by Webb et al. (2007) for R. canadum (5.18 to $5.29 \% \mathrm{BW}^{\text {day }}$ $\left.{ }^{1}\right)$ and by Do-Huu et al. (2018) for Trachinotus ovatus (3.15 to $3.26 \%$ BW day $^{-1}$ ), but similar to the one reported by Palstra et al. (2015) for Seriola lalandi $\left(2.1 \% \mathrm{BW} / \mathrm{day}^{-1}\right)$, and superior to the values reported by authors such as Weirich et al. (2009) for Trachinotus carolinus $(0.81 \% \mathrm{BW}$ day $\left.^{-1}\right)$, Álvarez-González et al. (2001) for Paralabrax maculatofasciatus $\left(1.73 \%\right.$ BW day $\left.{ }^{-1}\right)$, and Merino et al. (2007) for Paralichthys californicus (1.18\% BW day $\left.{ }^{-1}\right)$.

Absolute growth of juveniles of L. pacificus (Table 2) after 100 days of cultivation indicates that this species reaches commercial sizes in less time compared to similar species such as L. surinamensis, which, according to Franks et al. (2001), obtained a $\Delta \mathrm{G}$ lower than the one found in this research for the same time period of study. However, the use of sardines as food for this group resulted in an inappropriate FCR (4.9 \pm 3.3$)$ for aquaculture as 
suggested by authors such as Botero \& Ospina (2003) for E. itajara (9.01 and 9.97) and Banguera-Gil \& AnguloSinesterra (2010) for L. guttatus (2.9). Juveniles in Tank 5 (D2) developed the largest infestation of parasites, although not the highest mortality, and had the highest FCR (5.8).

In marine fish culture, diets need to adjust not only to nutritional requirements but to the physical and taste characteristics that each species requires. In the case of $\mathrm{D} 1$, low growth values could be explained by the lack of appetite for the feed provided and low consumption. In addition, the neutral buoyancy of the feed influenced intake, as fish prefer food found in the first centimeters of the water column, a fact that could be related to the natural behavior of the species when they inhabit and hunt among floating objects in their natural environment (Heemstra, 1995; Lea et al. 2010). Franks et al. (2001) obtained a high AGR (4.9g day $\left.{ }^{-1}\right)$ by feeding L. surinamensis juveniles with a commercial diet in recirculation systems. The coefficients of the lengthweight relationship obtained for both groups at the end of the investigation (Fig. 3) were similar to the coefficients obtained for fish of the same species captured in the Colombian Pacific with $\mathrm{R}^{2}=0.936$ (Leiva et al. 2007), and for specimens of L. surinamensis captured in Georgia (U.S.A) with $\mathrm{R}^{2}=$ 0.985 (Parr, 2001).

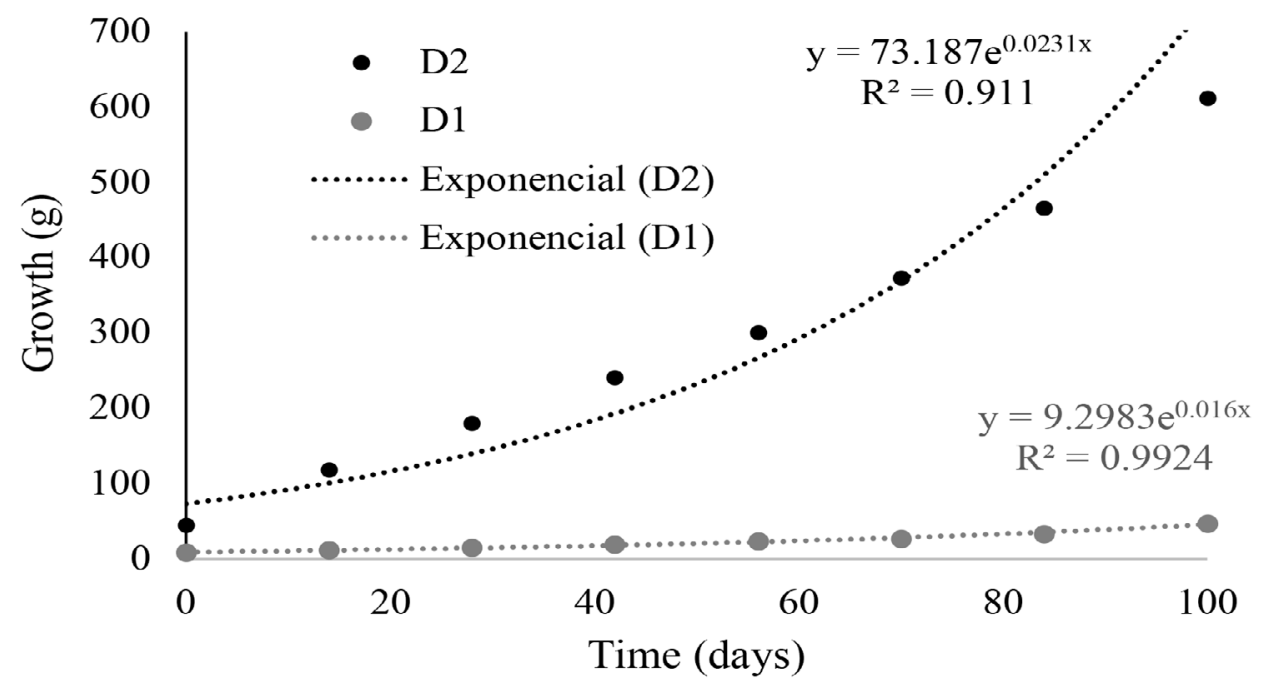

Fig. 3. Growth line of L. pacificus in two treatments at the Pacific Marine Park

Fig. 3. Línea de crecimiento de L. pacificus con dos tratamientos en el Parque Marino del Pacífico 
In the length-weight relationship, coefficient $b$ is related to the type of growth; isometric $(b=3)$, negative allometric $(<3)$, and positive allometric (>3) (Ricker, 1975; Pauly, 1984). In this study, $b$ values obtained in each group were negative allometric in D1 with weight and length ranges between 5.0-106.3 $\mathrm{g}$ and 5.8-18.9 $\mathrm{cm}$, which indicates that fish first increased in length and then in weight; and positive in D2 with weight and length ranges between 14.2-1168.0 $\mathrm{g}$ and 9-36 $\mathrm{cm}$ (Fig. 1), which indicates that this group first increased in weight and then in length. It is inferred that this variation in the $b$ value between the groups is due to differences in size and weight ranges for each group at the beginning of the study since the coefficient can change between populations of the same species depending on life cycle stages (Bagenal, 1978; Cibert et al. 1999; Sá et al. 2000; Possamai et al. 2018), as well as to the low consumption of feed in D1 with respect to the high consumption of sardine in D2. Both $b$ values were higher than those found by Leiva et al. (2007) for the same species captured in Colombian waters $(b=2.656)$.

The condition factor $K$ is defined as the degree of wellbeing or somatic condition of a species in relation to the environment in which it lives (Bagenal, 1978; Froese, 2006). In both groups, no environmental or physical-chemical disturbances were detected that were related to the irregularities shown in $K$. In D1, low food consumption was the only recorded disruptive event, which according to Rennie and Verdon (2008) can clearly affect the condition of organisms. Fish showed a greater appetite for food during the first period of cultivation than in the rest of the periods, which coincided with the changes in $K$ (Fig. 2).

In D2, the condition factor increased from the first to the third sampling period, but this trend did not continue in the following periods (Fig. 2), which was related to the infestation with Benedenia $s p$. According to Untergasser (1989) and Noga (1996), this trematode is considered opportunistic; therefore, it is inferred that the infestation was not due to a special susceptibility of the species to the infectious agent but to the conditions of cultivation, which were affected by the type of food used. Infestations with this type of parasite caused mortality in the culture of Atlantic goliath grouper, $E$. itajara, which was also fed with fish in floating cages in Colombia (Botero \& Ospina, 2003), and reported a gradual decrease in $K$ values through the study. In comparison with other marine fish, the range of $K$ values of group D2 (2.02-2.65) was similar to the one reported by Orellana et al. (2014) in $S$. Lalandi (1.9-2.9) and higher to the one described by Hernández et al. (2015) in L. guttatus (1.75 and 1.76). 
The eviscerated yield showed a high percentage of utilization. Similar eviscerated yields were found in species such as $R$. canadum $87.3 \%$ (2.86 Kg) (Gutiérrez et al. 2016) and Oncorhynchus mykiss 83\% (300-370 g) (Souza et al. 2015). The filletto-skin yield was lower than the one reported in other marine fishes such as $R$. canadum $52 \%(2.86 \mathrm{Kg})$ (Gutiérrez et al. 2016) and D. labrax $42 \%$ to $47 \%$ (Vandeputte et al. 2019). However, the fillet yield found in this study (Table 3) is within the range (33.2-39.05\%; 250-600 g) obtained for crops of Nile tilapia (O. niloticus), one of the most commercialized and successful species in worldwide aquaculture (Silva et al. 2009).

In conclusion, L. pacificus is a species that can be cultured and that has high growth rates allowing for a short grow-out period before harvest, which was shorter than the one required for other currently cultured species of marine fish. In addition, L. pacificus had yields similarly acceptable to those of well-established species in international markets.

Therefore, L. pacificus is a species with high potential for largescale commercial aquaculture. The present study is the beginning of a series of investigations concerning the development of technology for the species production. Based on the results of this study, appropriate methods should be defined to achieve natural reproduction in captivity and formulate a specific balanced diet suitable for the culture of all stages of the species life cycle.

\section{REFERENCES}

Álvarez-González, C., Civera-Cerecedo, R., Ortiz-Galindo, J., Dumas, S., MorenoLegorreta, M. \& Grayeb Del Alamo, T. (2001). Effect of dietary protein level on growth and body composition of juvenile spotted sand bass, Paralabrax maculatofasciatus, fed practical diets. Aquaculture, 194(1), 151159. https://doi.org/10.1016/S00448486(00)00512-3

Arias, A., Pereira, D., Senior, A. \& Tellez C. (2007). Pesca y Acuicultura Colombia. Bogotá, Colombia: Corporación Colombia Internacional.

Asamblea Legislativa de la República de Costa Rica. (1994). Ley de Bienestar de los Animales. Ley 7451. (Published in the Official Gazette $\mathrm{N}^{\circ} 236$, November 11). San José, Costa Rica: Imprenta Nacional.

Bagenal, T. (1978). Methods for assessment of fish production in fresh waters. New York, USA: Blackwell Scientific Publications.

Banguera-Gil, E. \& Ángulo-Sinisterra, J. (2010). Crecimiento en jaulas del pargo lunarejo Lutjanus guttatus (Steindachner, 1869) con dos tipos de dieta en Bahía Málaga, municipio de Buenaventura, Colombia. Entramado, 12, 12-23.

Benetti, D., O'Hanlon, B., Rivera, J., Welch, A., Maxey, C. \& Orhun, M. (2010). Growth rates of cobia (Rachycentron canadum) cultured 
in open ocean submerged cages in the Caribbean. Aquaculture, 302(3), 195-201. https://doi.org/10.1016/j. aquaculture.2010.02.021

Benitez-Hernández, A., Jiménez-Bárcenas, S. \& Sánchez-Gutiérrez, E. (2017). Use of marine by-product meals in diets for juvenile longfin yellowtail Seriola rivoliana. Aquac. Nutr. 24(1), 562-570. https://doi.org/10.1111/anu. 12588

Blancheton, J. (2000). Developments in recirculation systems for Mediterranean fish species. Aquacult. Eng., 22(1), 17-31. https://doi.org/10.1016/S01448609(00)00030-3

Botero, J. \& Ospina, J. (2002). Crecimiento de juveniles de pargo palmero Lutjanus analis (Cuvier) en jaulas flotantes en islas del rosario, Caribe Colombiano. Bol. Investig. Mar. Cos., 31, 205-217.

Botero, J. \& Ospina, J. (2003). Crecimiento $\mathrm{y}$ desempeño general de juveniles silvestres de mero guasa Epinephelus itajara (Lichtenstein) mantenidos en jaulas flotantes bajo diferentes condiciones de cultivo. Bol. Investig. Mar. Cost., 32, 25-36.

Busacker, P., Adelman, R. \& Goollish, M. (1990). Growth. In B. Schreck \& B. P. Moyle (Eds.), Methods for Fish Biology (pp. 363-387). Maryland, USA: American fisheries.

Castillo-Vargasmachuca, S., Ponce-Palafox, J., Arámbul-Muñoz, E., RodríguezDomínguez, G. \& Aragón-Noriega, E. (2016). The spotted rose snapper (Lutjanus guttatus Steindachner 1869) farmed in marine cages: review of growth models. Rev. Aquacult., 10 (2), 376- 384. https://doi.org/10.1111/ raq. 12166

Cibert, C., Fermon, Y., Vallod, D. \& Meunier, F.J. (1999). Morphological screening of carp Cyprinus carpio: relationship between morphology and fillet yield.
Aquat. Living Resour., 12, 1-10. https://doi.org/10.1016/S09907440(99)80009-6

Di Rienzo J. A., Casanoves F., Balzarini M. G., Gonzalez L., Tablada M. \& Robledo C. W. (2018). InfoStat. Buenos Aires, Argentina: Grupo InfoStat, FCA.

Do-Huu, H., Ho-Son, L. \& Can-Van, N. (2018). Efficiency of Dietary $\beta$-glucan Supplementation on Growth, Body Composition, Feed, and Nutrient Utilization in Juveniles of Pompano Fish (Trachinotus ovatus, Linnaeus, 1758). The Israeli J. Aquacult., 70, 1-17.

Franks, J., Ogle, J., Hendon, J., Barnes, D. \& Nicholson, L. (2001). Growth of captive juvenile tripletail Lobotes surinamensis. Gulf Caribb. Res., 13(1), 67-70. https://doi.org/10.18785/ gcr.1301.07

Froese, R. (2006). Cube law, condition factor and weight-length relationships: history, meta-analysis, and recommendations. J. Appl. Ichthyol, 22, 241-253. https://doi.org/10.1111/ j.1439-0426.2006.00805.x

García-Rojas, A., Vega-Bolaños, H. \& Quesada-Phillips, V. (2017). Dinámica anual de tintínidos en las aguas estuarinas de dos áreas marinas de pesca responsable en el Golfo de Nicoya, Costa Rica. Uniciencia, 31(1), 1-12.

Gutiérrez, E., Hoyum, M., Cruzata, P., Lunestad, B., Villalobos, L., Karlsen, O. \& Alfonso, Y. 2016. Manejo postcosecha de la cobia de cultivo en la bahía de Cochinos. Rev. Cub. Invest. Pesq., 33(1), 72-75.

Heemstra, C. (1995). Lobotidae Dormilonas. In W. Fischer, F. Krupp, W. Schneider, C. Sommer, K.E. Carpenter \& V. Niem (Eds.), Guía de las Naciones Unidas para la Alimentación (FAO) 


\section{$\because$ REVMAR

para Identificación de Especies para los Fines de la Pesca (p. 1226). Rome, Italy: FAO.

Hernández, C., Ibarra-Castro, L., Hernández, C., Quintero-Martínez, G., AragónNoriega, A. \& Tacon, A. (2015). Growth performance of spotted rose snapper in floating cages and continuous water-flow tank systems. N. Am. J. Aquacult., 77(4), 423-428. https://doi. org/10.1080/152 2055.2015.1032458

Jobling, M. (1994). Fish Bioenergetics. London, England: Chapman \& Hall.

Lea, R. N. \& Rosenblatt, R. (2000). Observations on Fishes Associated with the 1997-1998. El Niño of California. Cal. Coop. Ocean. Fish, 41, 117-129.

Lea, R., Bearez, P., van der Heiden, A., Acero, A. \& Cotta, A. (2010). Lobotes pacificus. Gland, Switzerland: The IUCN Red List of Threatened Species.

Leiva, A., Bonilla, D., Mojica, A. \& Murcia, C. (2007). Pesca y Acuicultura Colombia. Bogotá, Colombia: Corporación Colombia Internacional.

Lima-Amancio, A., Vilar da Silva, J., Kochenborger-Fernandes, J., KazueSakomura, N. \& Beltrão da Cruz, G. (2014). Use of mathematical models in the study of bodily growth in GIFT strain Nile tilapia. Rev. Ciênc. Agron, 45(2), 259-266.https://doi.org/10.1590/ S1806-66902014000200005

Merino, G., Piedrahita, R. \& Conklin, D. 2007. The effect of fish stocking density on the growth of California halibut (Paralichthys californicus) juveniles. Aquaculture, 265(1), 176-186. https://doi.org/10.1016/j. aquaculture.2007.01.028

Murase, A., Angulo, A., Miyazaki, Y., Bussing, W. \& López, M. (2014). Marine and estuarine fish diversity in the inner Gulf of Nicoya, Pacific coast of Costa
Jonathan Chacón-Guzmán, Milagro Carvajal-Oses, Ángel Herrera-Ulloa \& Pedro Toledo-Agüero

Rica, Central America. Check List, 10(6), 1401-1413

Nelson, S., Crossman, E., Espinosa-Perez, H., Findley, L., Gilbert, C., Lea, R. \& Williams, J. (2004). Common and scientific names of fishes from the United States, Canada, and Mexico. Maryland, USA: American Fisheries Society.

Noga, E. (1996). Fish disease: diagnosis and treatment. North Carolina, USA: Mosby-Year Book.

Orellana, J., Waller, U. \& Wecker, B. (2014). Culture of yellowtail kingfish (Seriola lalandi) in a marine recirculating aquaculture system (RAS) with artificial seawater. Aquacult. Eng., 58, 20-28. https://doi.org/10.1016/j. aquaeng.2013.09.004

Palstra, A., Mes, D., Kusters, K., Roques, J., Flik, G., Kloet, K. \& Blonk, R. (2015). Forced sustained swimming exercise at optimal speed enhances the growth of juvenile yellowtail kingfish (Seriola lalandi). Front. Physiol., 5, 506. https:// doi.org/10.3389/fphys.2014.00506

Parr, R. (2001). Age, growth, and reproductive status of tripletail (Lobotes surinamensis) in the aggregation near shore Jekyll Island, GA, USA. Unpublished master's thesis, University of Georgia.

Pauly, D. (1984). Fish population dynamics in tropical waters: A manual for use with programmable calculators. Manila, Philippines: International Center for Living Aquatic Resources Management ICLARM.

Possamai, B., Zanlorenzi, D., Machado, R. C. \& Fávaro, L. F. (2018). Length-weight relationships for estuarine fishes in South Brazil. J. Applied Ichthy., 35, 608-613. https://doi.org/10.1111/ jai. 13846 
Ramírez, J. (2004). Síndromes de sostenibilidad ambiental del desarrollo en Colombia. Santiago, Chile: United Nations Publications.

Rennie, M. \& Verdón, R. (2008). Development and Evaluation of Condition Indices for the Lake Whitefish. N. Am. J. Fish. Manage., 28, 1270-1293. https://doi. org/10.1577/M06-258.1

Ricker, W. (1975). Computation and interpretation of biological statistics of fish population. B. Fish. Res. Board. Can., 191, 1-382.

Sá, M., Barbieri, G. \& Verani, J. (2000). Análise do comportamento de Cyprinus carpio, Prochilodus cearensis e Colossoma macropomum em experimento de policultivo, embasado nos factores de condição. Bol. Inst. Pesca, 26(2), 181187.

Silva, F., Franco, N., Vieira, J., Tessitore, A., Oliveira, L. \& Saraiva, E. (2009). Características morfométricas, rendimentos de carcaça, filé, vísceras e resíduos em tilápias do Nilo em diferentes faixas de peso. Rev. Bras. Zootecn., 38(8), 1407-1412. https://doi.org/10.1590/S151635982009000800003

Souza, M., Macedo-Viegas, E., Zuanon, J., Carvalho, M. \& Goes, E. (2015). Processing yield and chemical composition of rainbow trout (Oncorhynchus mykiss) with regard to body weight. Acta Sci. Anim. Sci., 37(2), 103-108. https:// doi.org/10.4025/actascianimsci. v37i2.24165

Tortonese, E. (1990). Lobotidae. In J. Quéro, J. Hureaus \& C. Karrer (Eds.), CheckList of the fishes of the Eastern Tropical Atlantic. Paris, France: UNESCO.

Untergasser, D. (1989). Handbook of fish diseases. Texas, USA: Neptune City.
Vandeputte, M., Gagnaire, P. \& Allal, F. (2019). The European sea bass: a key marine fish model in the wild and in aquaculture. Anim. Genet., 50(3), 195206. https://doi.org/10.1111/age.12779

Vela, M. A., Villarreal, H., Araneda, M. \& Espinosa-Faller, F. J. (2018). Growth and survival of juvenile red drum, Sciaenops ocellatus, acclimated to freshwater at three different stocking densities in a partial recirculation system. J. World Aquacult. Soc., 1, 1-17. https://doi.org/10.1111/ jwas. 12546

Webb, K., Hitzfelder, G., Faulk, C. \& Holt, G. (2007). Growth of juvenile cobia, Rachycentron canadum, at three different densities in a recirculating aquaculture system. Aquaculture, 264(1), 223-227. https://doi. org/10.1016/j.aquaculture.2006.12.029 Weirich, C., Wills, P., Baptiste, R., Woodward, P. \& Riche, M. (2009). Production characteristics and body composition of Florida pompano reared to market size at two different densities in lowsalinity recirculating aquaculture systems. N. Am. J. Aquacult. 71(2), 165-173. https://doi.org/10.1577/A08016.1

Zemnukhov, V. \& Turanov, S. (2011). First catch in Russian waters of a spinulated specimen of Lobotes surinamensis (Bloch, 1790) (Percoidei: Lobotidae) with notes on the taxonomy of this species. J. Ichthyol., 51(1), 84-89. https://doi.org/10.1134/ S0032945211010164 
